\title{
Pelvic Organ Prolapse in Countries of Different Economy: A Systematic Review
}

\author{
Shishir Paudel ${ }^{1}$, Anisha Chalise ${ }^{2}$, Ganesh Dangal ${ }^{3}$, Tulsi Ram Bhandari ${ }^{4}$, Gehanath Baral ${ }^{5}$ \\ ${ }^{1}$ Manmohan Memorial Institute of Health Sciences, Kathmandu, Nepal \\ ${ }^{2}$ Central Department of Public Health, Institute of Medicine, Tribhuvan University, Kathmandu, Nepal \\ ${ }^{3}$ Department of Obstetrics and Gynecology, Kathmandu Model Hospital, Kathmandu, Nepal \\ ${ }^{4}$ Department of Public Health, School of Health and Allied Sciences, Pokhara University, Nepal \\ ${ }^{5}$ Paropakar Maternity and Women's Hospital, National Academy of Medical Sciences, Kathmandu, Nepal
}

Received: November 1, 2019

Accepted: December 5, 2019

\begin{abstract}
Aims: This review was done to identify the reported prevalence rate of pelvic organ prolapse among the different world populations. Methods: Systematic review of Pelvic Organ Prolapse (POP)usingthe PRISMA checklist; PubMed database was searched on reportingthe prevalence of POP and its management measuresin January 2020. Medical Subject Headings (MeSH) like "Pelvic Organ Prolapse"OR "Uterine Prolapse" OR "Vaginal Wall Prolapse" OR "Cystocele"AND "Prevalence" [key word/s] were used. Additional articles were identified through the reference list of the retrieved articles.
\end{abstract}

Results: Out of 91 screenedarticles, 46 full articles were eligible and only 15 satisfied by selection criteria for the systematic review.The methodological score rated for the quality of studies is $4.5 \pm 1.7$ (range $=2-7$ ) out of 8 points. The mean prevalence of POP diagnosis was $40 \%$; with $42.44 \%$ in low and lower-middle-income countries, and 35.56\%in upper-middle and high-income countries.Increasing age and parity, body mass indexand fetal macrosomia were found to be the significant risk factors irrespective of the country's economy.

Conclusions: The low and lower-income countries have almost twice the burden of prolapse than the countries of the higher economy. The major risk factors associated with prolapse remain common in all countries irrespective of national income or development.

Keywords: pelvic organ prolapse, prevalence, risk factors, systematic review

Citation : Paudel S, Chalise A, Dangal G, Bhandari TR, Baral G. Pelvic Organ Prolapse in Countries of Different Economy: A Systematic Review.Nep J Obstet Gynecol. 2019;14(29):7-21. DOI:https://doi.org/10.3126/njog.v14i2.28436.

\section{INTRODUCTION}

Pelvic organ prolapse is characterized by the descent of one or more pelvic organs (such as the anterior vaginal wall, posterior vaginal wall, the uterus/ cervix or the apex of the vagina)due tovaginal vault or cuff scar after hysterectomy from their normal position. ${ }^{1}$ This results when a weakened pelvic musculature collapses due to aging, childbirth, gynecological cancer treatment or heavy lifting and can no longer support the proper positioning of the pelvic organs, most commonly the vagina and uterus. ${ }^{2}$ Pelvic organ prolapse is considered to be a major cause of morbidity among women in both high- income and low-income countries. ${ }^{3}$ A systematic review performed on the global burden of disease studies in 2010 illustrated that genital prolapse is present in about 316 million women worldwide with a prevalence of $9.3 \%$ globally. ${ }^{4}$ Similarly, another systematic review performed on thirty studies sampled in low-income and lower-middle-income countries notified that the mean prevalence for pelvic organ prolapse lies at $19.7 \%$ with the prevalence range of 3.4 to $56.4 \%$ in developing nations. ${ }^{5}$ Thecountries are classified into four categories as low income, lowermiddle-income and upper-middle-income countries based on the Gross National Income per capita. ${ }^{6}$

\section{CORRESPONDENCE}

Dr Ganesh Dangal

Department of Obstetrics and Gynecology, Kathmandu Model

Hospital, Kathmandu

Phone: +977-9851055036; Email: ganesh.dangal@gmail.com 
Pelvic organ prolapse leads to several consequencesdifficulty in urination, painful intercourse, itching, and white-watery discharge, difficulty in lifting, walking and sitting, urinary tract infections, abdominal and back pain, lowered self-esteem,which in turnaffect women'squality of life and have a social, psychological and sexual impact. ${ }^{7,8}$ The treatment options for prolapse depend on the severity of the symptoms like conservative non-surgical (pelvic floor exercise, biofeedback, electrical stimulation, and vaginal pessaries) to definite surgical modalities. ${ }^{9,10}$ The use of pessary can also yield significant improvements in women's quality of life which issimilar to that of surgery as demonstrated by a systematic review performed by Coelho et al 2016. ${ }^{10-13}$ Based on the available literature, in the past years, there was no systematic review of studies to examine the disparity that lies between different nations and population characteristics in terms of pelvic organ prolapse. In light of this research gap, this review aims to identify the reported prevalence rate of pelvic organ prolapse among the different world populations.

\section{METHODS}

The search for the original research articles relevant to the prevalence of the POP wasperformed using the PRISMA checklist. ${ }^{14}$ The search was limited to publications indexed in the PubMed database and published between January 2000 to January 2020, reporting on the prevalence of POP. The search was performed using a combination of the Medical Subject Headings (MeSH) terms such as: "Pelvic Organ Prolapse"OR "Uterine Prolapse" OR "Vaginal Wall Prolapse" OR "Cystocele"AND "Prevalence" [key term/s]. Additional articles were identified through the reference list of the retrieved articles. Finally, we reviewed fifteen full texts which established the prevalence of POP and its risk factors.From the included publications,participant's demographic data, sample size, applied diagnostic instruments for prolapse and prevalence data were abstracted.

\section{Quality evaluation of articles}

The process of determining the studies toinclude in the review was performed by two independent reviewers (AC and SP).Title and the abstracts of the identified studies were assessed for relevance to the topic, and the full texts of the appropriate studies were obtained for further evaluation. The included articles were read extensively using the critical appraisal tool provided by Loney and colleagues. ${ }^{15}$ This tool was adaptedfor critical appraisal of health research literature based on prevalence or incidence of health problems.Article scored one point for each of the following quality markers: (i) the study design and sampling method appropriate for research question, (ii) the study had appropriate and unbiased sampling frame, (iii) the study had adequate sample size, (iv) the study used objective, suitable and standard criteria to measure prolapse status in the sample population, (v) the study measured prolapse status by unbiased assessors, (vi) the study is provided with adequate response $(>70 \%)$ or participant refusal is described, (vii) the study provided the confidence interval of estimated prevalence, and (viii) the study subjects and setting is described in detail. ${ }^{15}$

\section{Search outcome}

For thisreview, we collected 91 articles; out of them, 85 from PubMed and 6 articles from the reference list of retrieved articles. From the collected articles, 45 were excluded after assessing the title and abstract because they did not fit the inclusion criteria of this review: i) three articles had no abstract, ii) 10 studies didn't match the aim of study iii) 32articles were the studies assessing prevalence of other factors in women with pelvic organ prolapse. After evaluating full texts of 46 articles, 31 studies were excluded because six were found to be review articles, 3 studies estimated prolapse based on population projection, 14 studies were found not aimed at estimating prevalence of prolapse, and six studies were focused on treatment of organ prolapse in affected women while two studies were performed in animal population. Thus, out of a total of 91 publications, only 15 studies satisfied all the inclusion and exclusion criteria [Figure-1]. Included studies were published from 2000 to 2020 with the samples drawn internationally. 


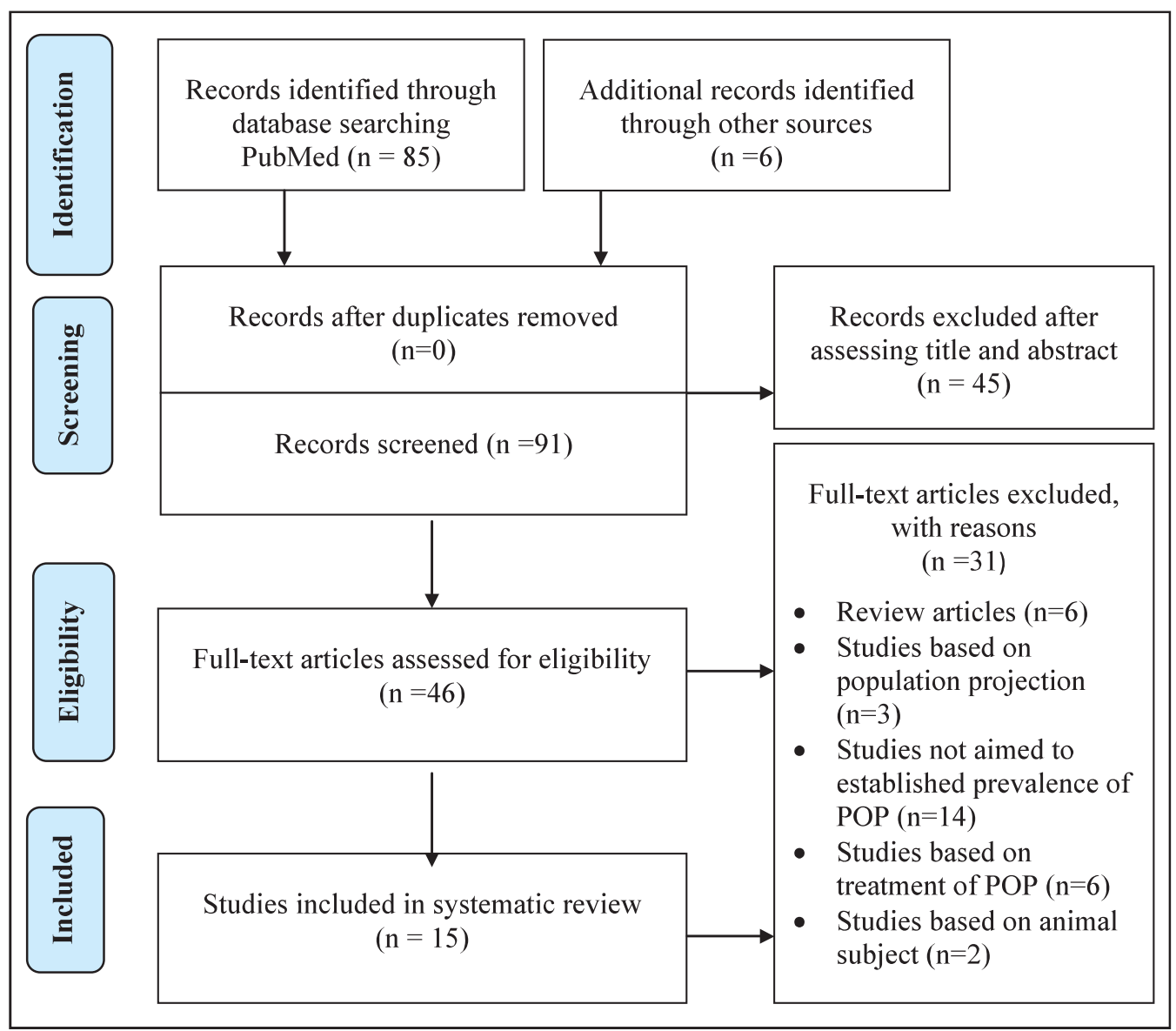

Figure-1: Literature search flow-chart

\section{RESULTS}

\section{Study characteristics and quality appraisal}

Out of 91 publications, only 15 studies satisfied all the inclusion criteria. Among the 15 studies included, the majority of them $(n=9)$ had been carried out in low and lower-middle-income countries. Three studies were carried out in Nepal, ${ }^{7,16,17}$ one in Ethiopia, ${ }^{18}$ one in the Gambia, ${ }^{19}$ one in Lebanon, ${ }^{20}$ one in Tanzania, ${ }^{21}$ one in Bangladesh ${ }^{22}$ and one in Ghana. ${ }^{8}$ Similarly, six studies had been sampled in upper-middle and highincome countries (one in Brazil, ${ }^{23}$ one in China, ${ }^{24}$ two in $\operatorname{Iran}^{25,26}$ one in Turkey, ${ }^{27}$ and one in $\left.\mathrm{UAE}^{28}\right)$.

All of the studies had adopted a cross-sectional design. The majority of studies (9) were conducted in community settings $\mathbf{s}^{7,8,17,19-22,24,26}$ while five studies were conducted at healthcare institutions s, $^{16,23,25,27,28}$ and one study was conducted in a working site of firewood sales. ${ }^{18}$ Almost half of the studies $(n=7)$ used random sampling technique ${ }^{8,17,19-21,24,26}$ while eight studies used convenience sampling technique. . $^{7,16,18,22,23,25,27,28}$ A range of measures were used to identify the status of pelvic organ prolapse in the target population by the studies included in this review. Valsalva maneuver performed in the dorsal lithotomy position or speculum examination and bimanual examination of pelvis were used to diagnose prolapse clinically by majority of the studies $(n=12){ }^{7,8,16,17,19-21,23-27}$ Three studies only assessed the symptomatic prolapse by interviewing the participants on their experienced symptoms of prolapse without any further clinical examination. ${ }^{18,22,28}$

The quality of all the 15 studies wasevaluated according to the criteria demonstrated in [Table-1]. According to these criteria as provided by Loney and colleagues ${ }^{15}$ the maximum possible score for quality is eight. The total score of the studies ranged from two to seven, with a mean score of $4.5 \pm 1.7 \mathrm{SD}$. 


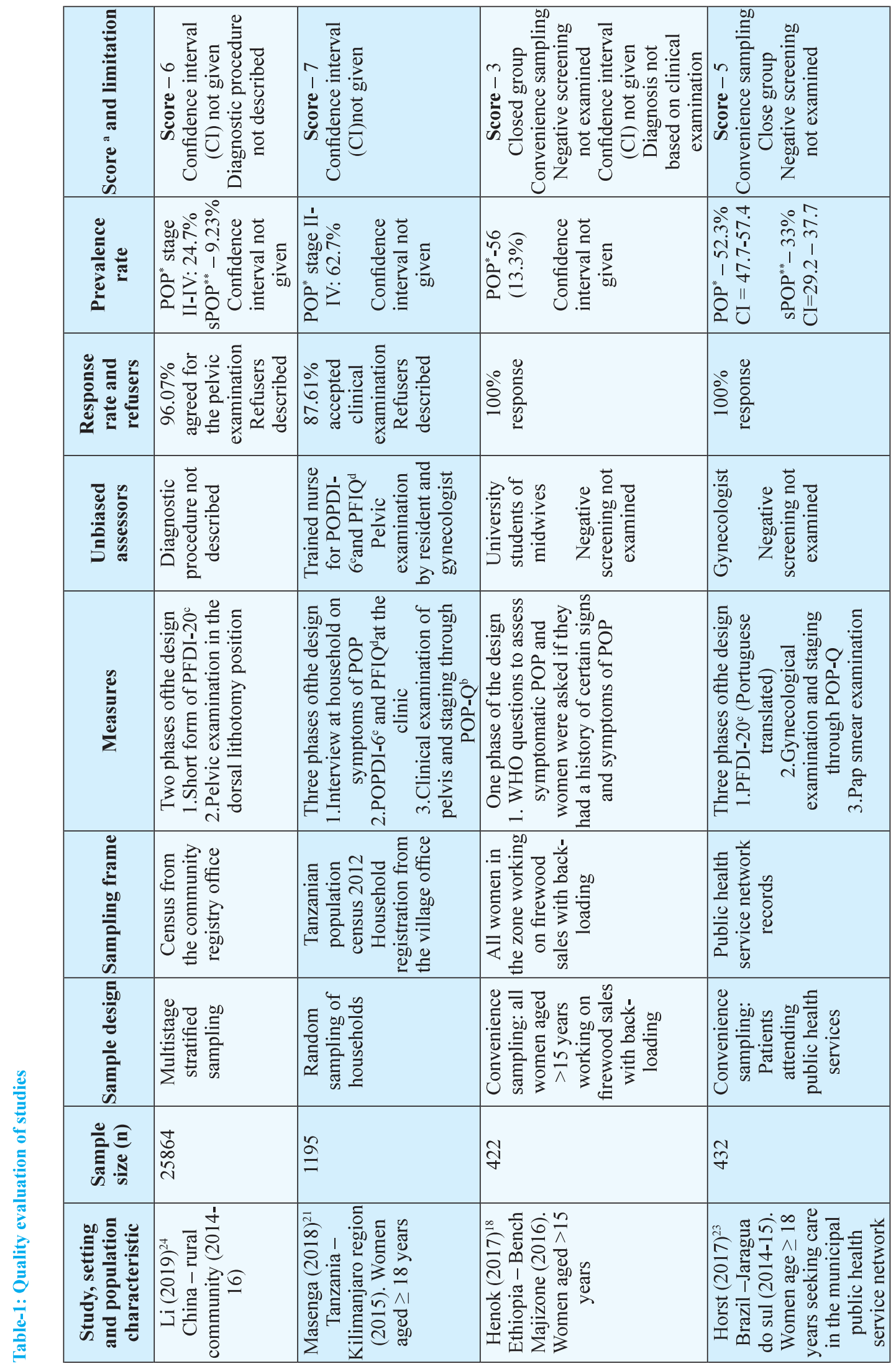




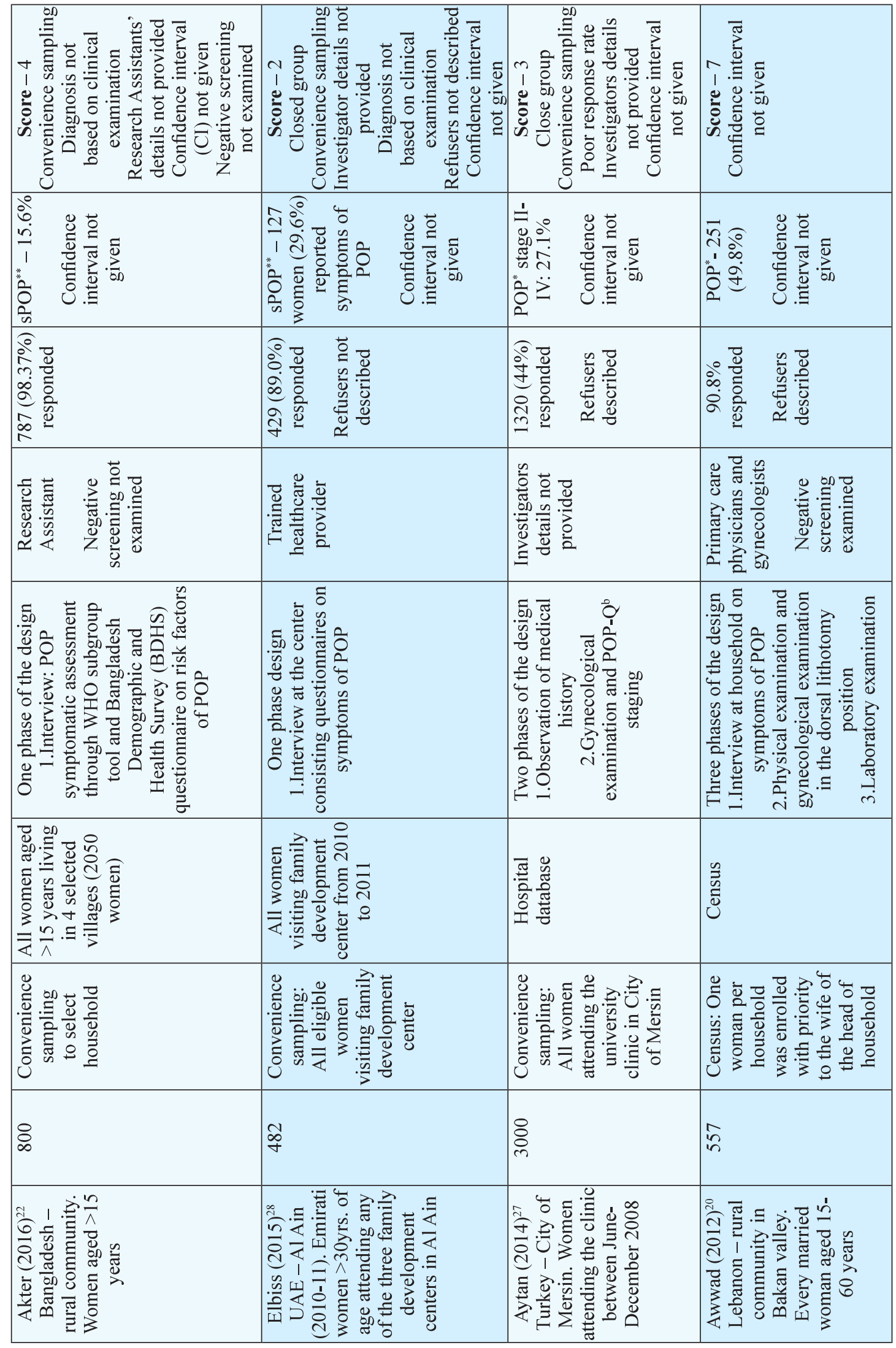




\begin{tabular}{|c|c|c|c|}
\hline 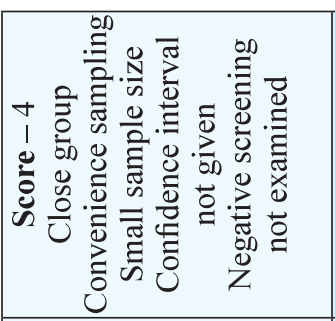 & 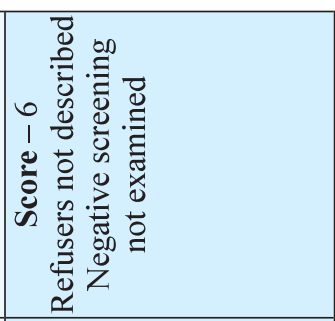 & 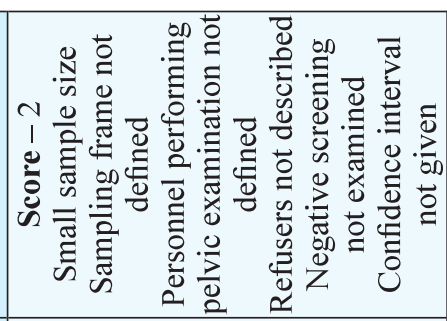 & 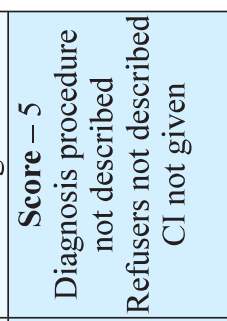 \\
\hline 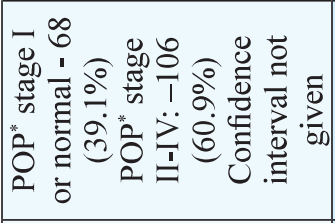 & 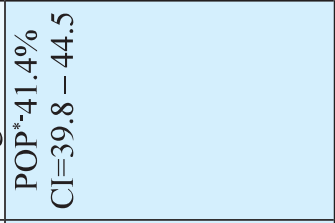 & 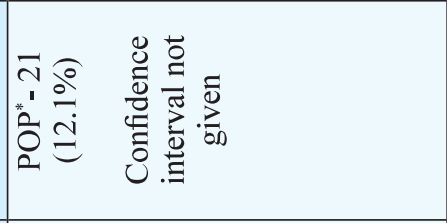 & 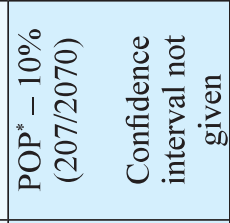 \\
\hline 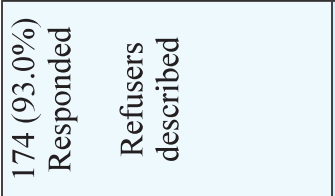 & 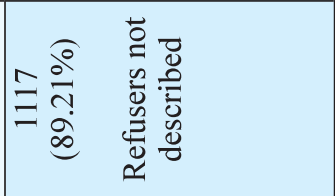 & 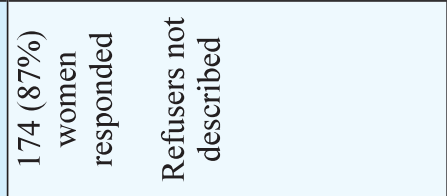 & 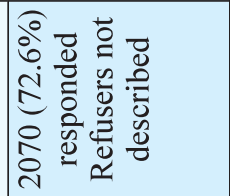 \\
\hline 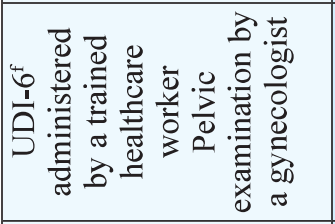 & 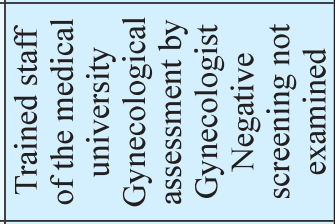 & 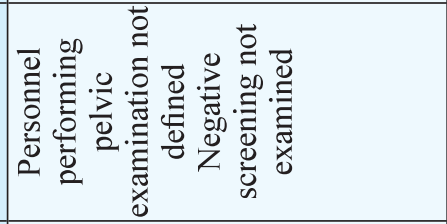 & 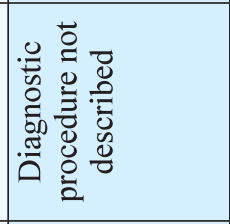 \\
\hline 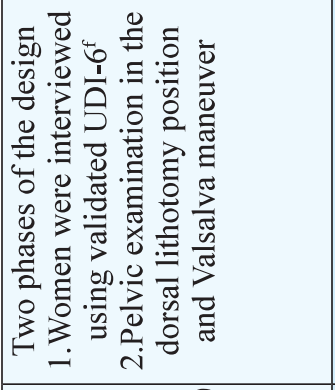 & 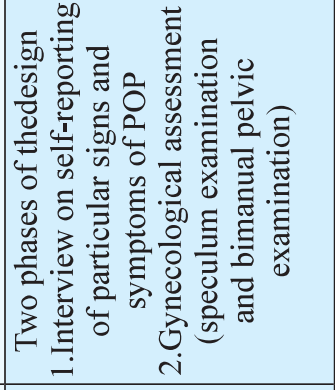 & 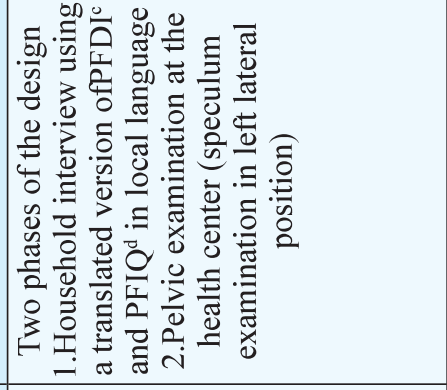 & 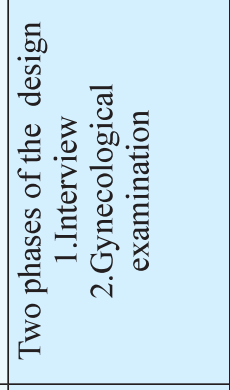 \\
\hline 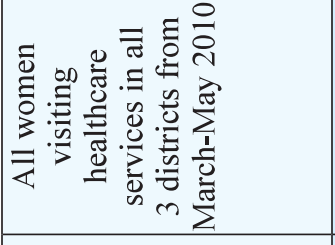 & 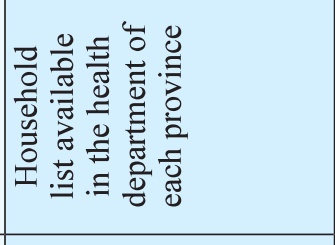 & 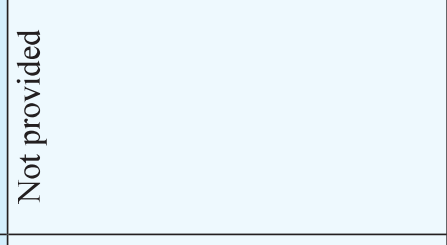 & 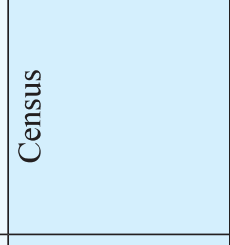 \\
\hline 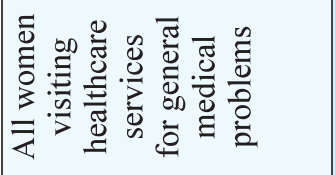 & 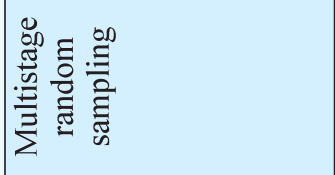 & 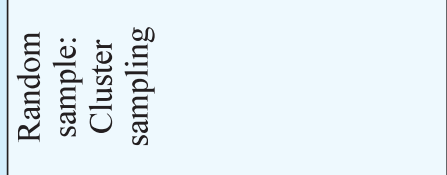 & 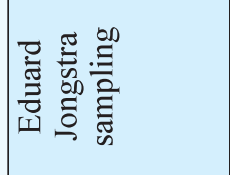 \\
\hline$\stackrel{\infty}{\infty}$ & 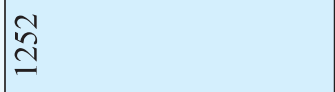 & 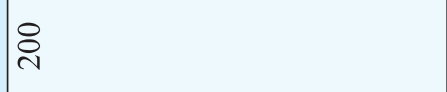 & 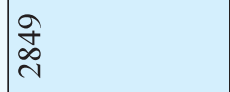 \\
\hline 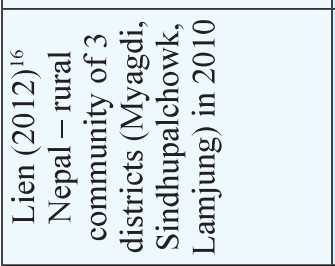 & 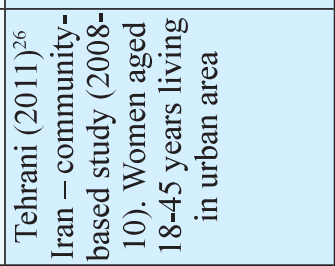 & 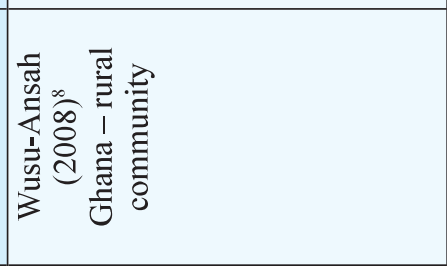 & 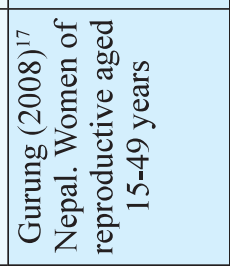 \\
\hline
\end{tabular}




\begin{tabular}{|c|c|c|c|}
\hline 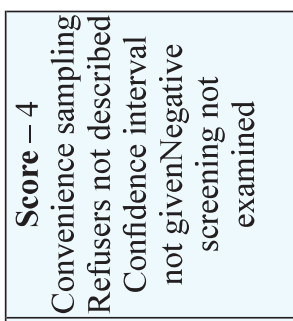 & 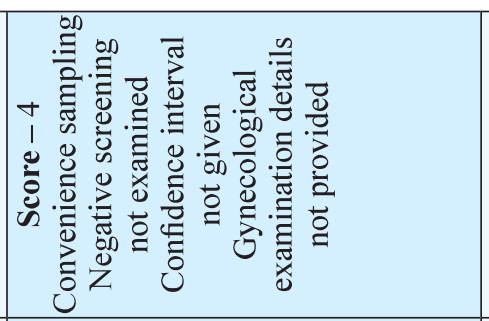 & 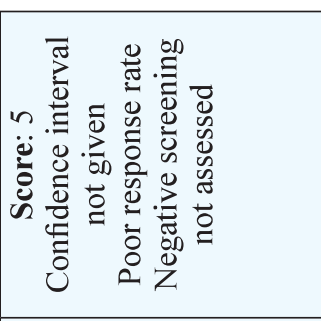 & 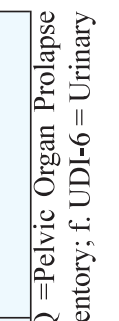 \\
\hline 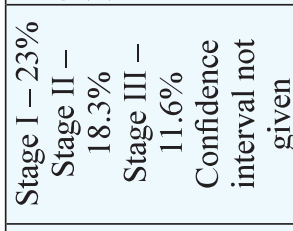 & 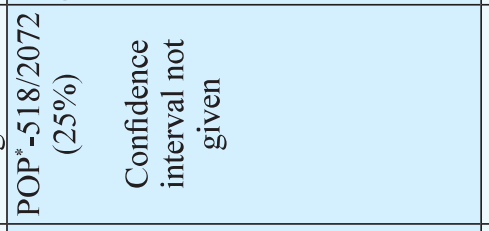 & 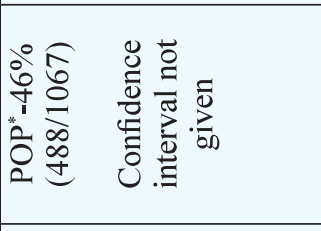 & $\begin{array}{l}\ddot{2} \\
\dot{0} \\
\ddot{\alpha} \\
\vdots \\
\vdots\end{array}$ \\
\hline 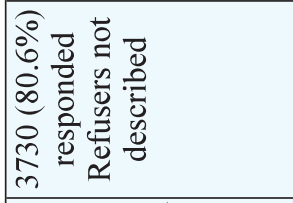 & & 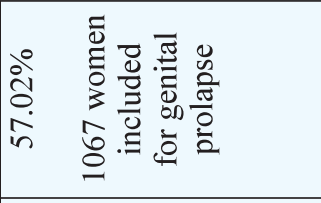 & $\begin{array}{l}\text { ह } \\
\text { E }\end{array}$ \\
\hline 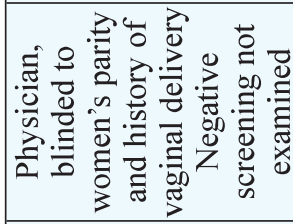 & 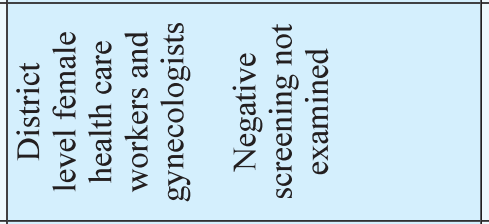 & 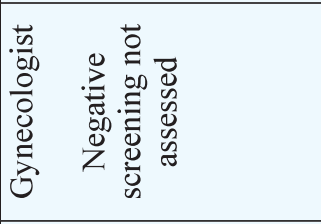 & 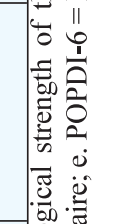 \\
\hline 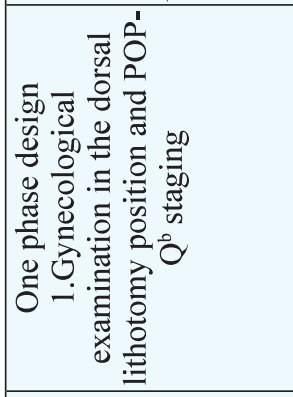 & 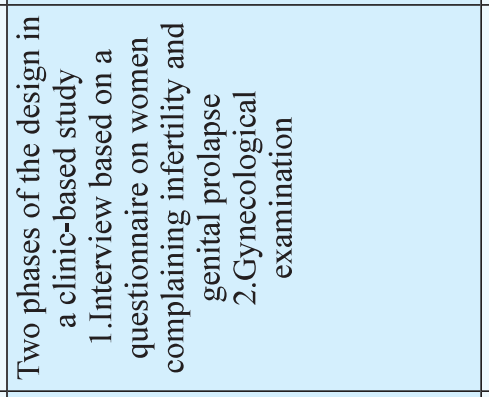 & 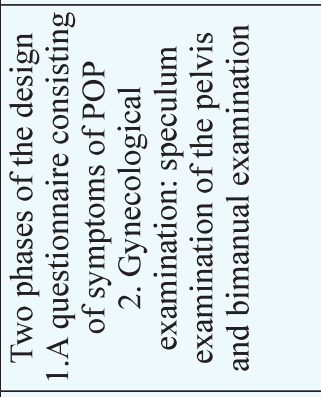 & 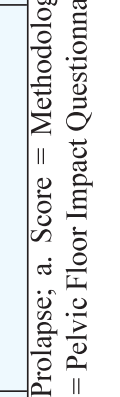 \\
\hline 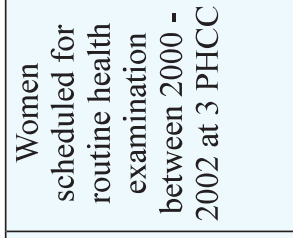 & 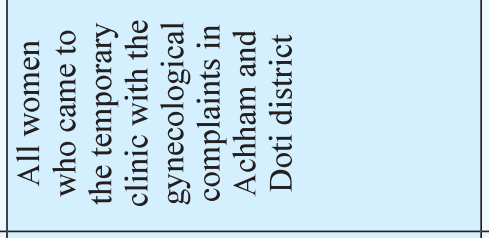 & 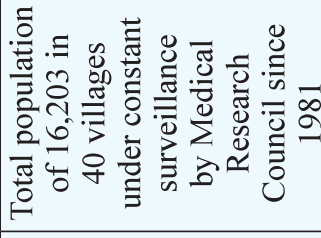 & 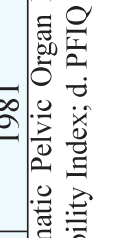 \\
\hline 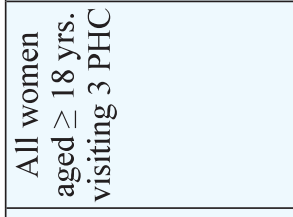 & 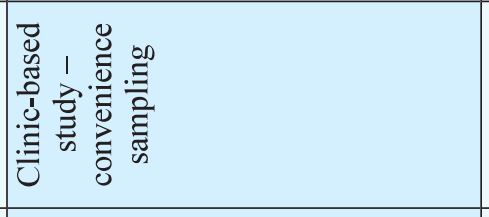 & 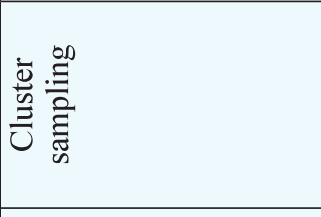 & $\|$ \\
\hline $\begin{array}{l}\text { గ్ } \\
\text { ర్ }\end{array}$ & 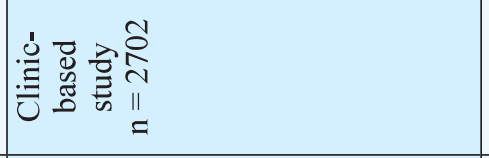 & $\stackrel{\infty}{\stackrel{\infty}{\infty}}$ & \\
\hline 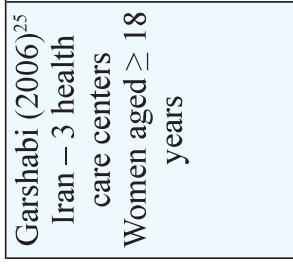 & 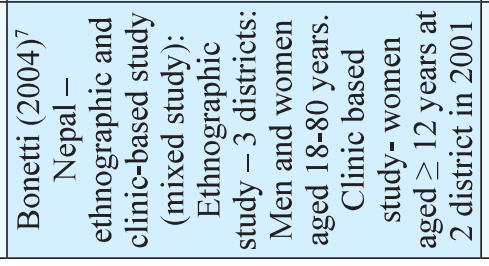 & 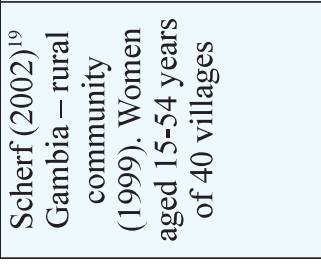 & \\
\hline
\end{tabular}




\section{Prevalence of pelvic organ prolapse}

A total of 40859 participants completed the study process in the selected 15 studies [Table- 2 and 3]. The age of the participants ranged from 12 to 99 years. Among the total participants, one fifth $(n=8130)$ participants had a certain degree of prolapse which was either symptomatic or clinically diagnosed. The prevalence of prolapse ranged from $9.23 \%$ to $93.4 \%$ in the selected fifteen studies ${ }^{7,8,16-28}$ with the mean prevalence of $35.91 \%$, but this included prevalence estimation based on pelvic examination and symptomatic diagnosis without pelvic examination. However, in the context of a pelvic examination, a total of twelve studies ${ }^{7,8,16,17,19-21,23-27}$ performed clinical diagnosis to assess the prevalence of prolapse with a mean prevalence of $40.01 \%$ (ranged $9.23 \%$ - 93.4\%) for prolapse of stage I-IV. Out of these twelve studies, only eight studies ${ }^{16,20,21,23-27}$ provided the prevalence of the different stages of prolapse which revealed the prevalence of clinically significant prolapse of stage II-IV ranging from $9.32 \%$ to $64.6 \%$ with the weighted mean prevalence of $33.27 \%$.

Regarding the economy of the nation,twelve studies thatdiagnosed prolapse clinically, the low and lowermiddle-income countries seem to have a higher prevalence than the upper-middle and high-income countries. The clinically diagnosed prolapse (stage I-IV) prevalence ranged from $10 \%$ to $93.4 \%$ with the mean of $42.44 \%$ in the context of low and lowermiddle-income countries, ${ }^{7,8,16,17,19-21}$ whereas in uppermiddle and high-income countries, it ranged from $9.23 \%$ to $53 \%$ with the mean prevalence of $35.56 \%{ }^{23-}$ 27 In the context of clinically significant prolapse (stage II-IV), out of eight studies that categorized prolapse status, three studies were sampled from low and lower-middle-income countries yielding a mean prevalence of $58.4 \%$ with the range of $49.8 \%$ to $64.6 \%{ }^{16,20,21}$ The remaining five studies were from upper-middle and high-income countries yielding a mean prevalence of $20.35 \%$ with a range of $9.23 \%$ to $29.9 \%$. $^{23-27}$

As regards to the sampling methodology used in all 15 studies, the range of prevalence reported from seven studies using a random sampling technique ${ }^{8,17,19-21,24,26}$ was $9.23 \%$ to $93.4 \%$ with the mean prevalence of $37.41 \%$. This was slightly higher than the mean prevalence obtained from eight studies using convenience sampling, $7,8,16,18,22,23,25,27,28$ where the prevalence ranged from $13.3 \%$ to $60.9 \%$ with the mean of $34.6 \%$. There was no notable difference found in the prevalence when comparing the studies having a small sample size (less than 300$)^{8,16}$ with those having large sample size $e^{7,17-28}$ as the reported mean prevalence from these studies were found to be $36.50 \%$ and $35.82 \%$ respectively.

Table-2: Prevalence of pelvic organ prolapse in countries of low and low-middle income economy.

\begin{tabular}{|c|c|c|c|}
\hline \multirow{2}{*}{ Study } & \multirow{2}{*}{ The operational definition of POP } & \multicolumn{2}{|c|}{ Prevalence } \\
\hline & & Frequency & Percentage \\
\hline $\begin{array}{l}\text { Tanzania }(2018)^{21} \\
\text { Age of women: } \\
\text { Median: } 46 \text { yrs. } \\
\text { Range: } 18-90 \text { yrs. }\end{array}$ & $\begin{array}{l}\text { Defined POP based on POP-Q classification system: (0- No } \\
\text { prolapse, I -The most distal portion of the prolapse is more } \\
\text { than } 1 \mathrm{~cm} \text { above the level of the hymen, II-The most distal } \\
\text { portion of the prolapse protrudes to } 1 \mathrm{~cm} \text { above and } 1 \mathrm{~cm} \\
\text { below the hymen, The most distal portion of the prolapse } \\
\text { protrudes more than } 1 \mathrm{~cm} \text { below the hymen but does not form } \\
\text { a complete prolapse, IV-Complete vaginal vault eversion or } \\
\text { procidentia uteri (complete prolapse)) }\end{array}$ & $\begin{array}{l}\text { Total }(\mathrm{n})= \\
1047 \\
\text { Stage I: } 302 \\
\text { StageII: } 666 \\
\text { Stage III:6 } \\
\text { Stage IV:4 } \\
\text { Stage } \geq \text { II }: 674\end{array}$ & $\begin{array}{c}28.8 \% \\
63.6 \% \\
0.6 \% \\
0.4 \% \\
64.6 \%\end{array}$ \\
\hline $\begin{array}{l}\text { Ethiopia }(2017)^{18} \\
\text { Age of women: } \\
\text { Median:46 yrs. } \\
\text { Range: } 18-90 \text { yrs. }\end{array}$ & $\begin{array}{l}\text { Pelvic organ prolapse is an anatomic support defect of the } \\
\text { pelvic viscera which results in the downward displacement of } \\
\text { structures that are normally located adjacent to the } \\
\text { vaginal vault }\end{array}$ & $\begin{array}{c}n=422 \\
\text { POP: } 56\end{array}$ & $13.3 \%$ \\
\hline $\begin{array}{c}\text { Nepal }(2012)^{16} \\
\text { Age of women: } \\
\text { Mean:40.4 yrs. } \\
\text { Range: } 16-80 \\
\text { years }\end{array}$ & $\begin{array}{l}\text { Defined for POP: stage } 0 \text { (no prolapse); stage I (most distal } \\
\text { portion of the prolapse }>1 \mathrm{~cm} \text { above the hymen); stage II } \\
\text { (most distal portion of the prolapse }>1 \mathrm{~cm} \text { proximal or distal } \\
\text { to the hymen); stage III (prolapse }>1 \mathrm{~cm} \text { below the hymen), } \\
\text { and stage IV (complete eversion of the length of the lower } \\
\text { genital tract) }\end{array}$ & $\begin{array}{c}n=174 \\
\text { Stage } \geq I I: 106\end{array}$ & $60.9 \%$ \\
\hline
\end{tabular}




\begin{tabular}{|c|c|c|c|}
\hline \begin{tabular}{|c|} 
Lebanon $(2012)^{20}$ \\
Age of women: \\
$15-60$ yrs.
\end{tabular} & $\begin{array}{l}\text { POP stage defined based on POP-Q classification system:(I: } \\
\text { Reference point remains at least } 1 \mathrm{~cm} \text { above the hymenal } \\
\text { remnants; II: Reference point descends to an area within } 1 \\
\mathrm{~cm} \text { up and down the hymeneal remnants; III: Reference point } \\
\text { descends greater than } 1 \mathrm{~cm} \text { past the hymeneal remnants, } \\
\text { without complete vaginal eversion; IV: Complete vaginal } \\
\text { eversion and uterine procidentia) }\end{array}$ & $\begin{array}{l}\mathrm{n}=504 \\
\text { StageII:170 } \\
\text { Stage III:73 } \\
\text { Stage IV:8 } \\
\text { Stage } \geq \text { II: } 251 \\
\end{array}$ & $\begin{array}{l}33.7 \% \\
14.5 \% \\
1.6 \% \\
49.8 \%\end{array}$ \\
\hline $\begin{array}{l}\text { Nepal }(2008)^{17} \\
\text { Age of women: } \\
15-49 \text { years }\end{array}$ & Not defined & $\begin{array}{c}n=2070 \\
\text { POP: } 207\end{array}$ & $10 \%$ \\
\hline $\begin{array}{l}\text { Nepal (2004) } \\
\text { Age of women } \\
\geq 12 \text { yrs. }\end{array}$ & Not defined & $\begin{array}{c}\mathrm{n}=2072 \\
\text { POP: } 518\end{array}$ & $25.1 \%$ \\
\hline $\begin{array}{c}\text { Gambia (2002) } \\
\text { Age of women: } \\
15-54 \text { yrs. }\end{array}$ & $\begin{array}{l}\text { Anterior prolapse- Mild cystocele (only visible after speculum } \\
\text { insertion); Moderate cystocele (vaginal mucosa overlying } \\
\text { bladder just visible at introitus without separating labia); } \\
\text { Severe cystocele (protrusion of bladder with an overlying } \\
\text { vaginal wall outside of the introitus); Urethrocele. Uterine } \\
\text { prolapse- Mild: 1st degree (into the vagina); Moderate: } 2 \text { nd } \\
\text { degree (cervix visible at introitus without labial separation); } \\
\text { Severe: 3rd degree, uterine descent outside of the introitus } \\
\text { (partial or complete procidentia). Posterior prolapse- Mild } \\
\text { rectocele: rectum protruding towards the anterior vaginal wall; } \\
\text { Moderate: rectocele (vaginal mucosa overlying the rectum } \\
\text { visible at the introitus without manual separation of labia); } \\
\text { Severe rectocele (protrusion of rectum with an overlying } \\
\text { vaginal wall extending outside the vaginal introitus); } \\
\text { Enterocele }\end{array}$ & $\begin{array}{c}\mathrm{n}=1067 \\
\text { POP: } 488\end{array}$ & $46 \%$ \\
\hline $\begin{array}{c}\text { Bangladesh }(2016)^{22} \\
\text { Age of women: }>15 \\
\text { years } \\
\text { Mean } \pm \text { SD:40.1 } \pm 9.0\end{array}$ & $\begin{array}{l}\text { The presence of symptomatic POP was ascertained by the } \\
\text { single question: "Do you feel anything coming out of your } \\
\text { vagina?" from the WHO subgroup }\end{array}$ & $\begin{array}{c}n=787 \\
\text { POP: } 123\end{array}$ & $15.6 \%$ \\
\hline $\begin{array}{c}\text { Ghana }(2008)^{8} \\
\text { Age of women :> } \\
15 \text { yrs. }\end{array} \mid$ & $\begin{array}{l}\text { Symptomatic prolapse was defined with a "yes" response to } \\
\text { any of the questions assessing the symptoms of prolapse.POP } \\
\text { was defined as the protrusion of the pelvic organs into or out of } \\
\text { the vaginal canal and was classified into regions, i.e., anterior, } \\
\text { posterior, cervix, and apical/cuff. The various combinations } \\
\text { were noted. }\end{array}$ & $\begin{array}{c}n=174 \\
\text { POP: } 21\end{array}$ & $12.1 \%$ \\
\hline
\end{tabular}

Table-3: Prevalence of pelvic organ prolapse in the upper-middle and high-income economy

\begin{tabular}{|c|c|c|c|}
\hline \multirow{2}{*}{ Study } & \multirow{2}{*}{ The operational definition of POP } & \multicolumn{2}{|c|}{ Prevalence } \\
\hline & & Frequency & Percentage \\
\hline $\begin{array}{l}\text { China }(2019)^{24} \\
\text { Age of women: } 20- \\
99 \text { yrs. } \\
\text { Mean } \pm \text { SD: } 45.40 \pm \\
15.77\end{array}$ & $\begin{array}{l}\text { The definition of symptomatic POP was an affirmative } \\
\text { response to any of the eight questions and the presence } \\
\text { of stage } \geq 2 \text { POP upon a physical examination in the } \\
\text { dorsal lithotomy position }\end{array}$ & $\begin{array}{l}\mathrm{n}=24848 \\
\text { Stage II: } 1875 \\
\text { Stage III: } 378 \\
\text { Stage IV: } 40 \\
\text { Stage } \geq \mathrm{II}: 2293\end{array}$ & $\begin{array}{l}7.55 \% \\
1.52 \% \\
0.16 \% \\
9.23 \%\end{array}$ \\
\hline $\begin{array}{l}\text { Brazil }(2017)^{23} \\
\text { Age of women: } \geq 18 \\
\text { yrs. }\end{array}$ & $\begin{array}{l}\text { POP stage defined based on POP-Q classification } \\
\text { system } \\
\text { POP was defined as the descent of one or more of the } \\
\text { anterior vaginal walls, posterior vaginal wall, the uterus } \\
\text { (cervix) or the apex of the vagina (vaginal vault or cuff } \\
\text { scar after hysterectomy (anatomical definition of the } \\
\text { sign of POP). }\end{array}$ & $\begin{array}{l}\mathrm{n}=432 \\
\text { Stage I: } 119 \\
\text { Stage II: } 100 \\
\text { Stage III: } 7 \\
\text { Stage IV: } 0 \\
\text { Stage } \geq \text { II: } 107\end{array}$ & $\begin{array}{l}27.5 \% \\
23.1 \% \\
1.6 \% \\
0 \% \\
24.7 \%\end{array}$ \\
\hline
\end{tabular}




\begin{tabular}{|c|c|c|c|}
\hline $\begin{array}{l}\text { Turkey } 2014)^{27} \\
\text { Age of women not } \\
\text { specified }\end{array}$ & $\begin{array}{l}\text { The staging of pelvic organ prolapse was done with } \\
\text { POP-Q (pelvic organ prolapse quantification) system. } \\
\text { Women with stage } 2 \text { prolapse were considered as having } \\
\text { genital prolapse }\end{array}$ & $\begin{array}{l}\mathrm{n}=1320 \\
\text { POP } \geq \mathrm{II}: 358\end{array}$ & $27.1 \%$ \\
\hline $\begin{array}{l}\text { Iran }(2011)^{26} \\
\text { Age of } \\
\text { women: } 18-45 \text { years } \\
\text { Mean } \pm \text { SD: } 33.2 \\
\pm 7.7\end{array}$ & $\begin{array}{l}\text { Pelvic organ prolapse (clinical examination): descending } \\
\text { of anterior and/or posterior vaginal wall and/or uterus } \\
\text { below their normal position using the standard protocol. } \\
\text { POP stage defined based on the POP-Q classification } \\
\text { system. }\end{array}$ & $\begin{array}{l}\mathrm{n}=967 \\
\text { Stage I }: 296 \\
\text { Stage II }: 77 \\
\text { Stage III }: 24 \\
\text { Stage IV }: 3 \\
\text { Stage } \geq \text { II: } 104\end{array}$ & $\begin{array}{l}30.6 \% \\
8.0 \% \\
2.5 \% \\
0.3 \% \\
10.8 \%\end{array}$ \\
\hline $\begin{array}{l}\text { Iran }(2006)^{25} \\
\text { Age of women: } \\
\text { Mean: } 36 \\
\text { Range: } 18-68 \text { yrs. }\end{array}$ & $\begin{array}{l}\text { POP-Q system stage defined as follows: stage } 0 \text {, showing } \\
\text { no prolapse being demonstrated; stage } 1 \text {, the most distal } \\
\text { portion of prolapse }>1 \mathrm{~cm} \text { above the hymen; stage } 2 \text {, the } \\
\text { most distal portion of prolapse }>1 \mathrm{~cm} \text { proximal or distal } \\
\text { to the plane of the hymen; stage } 3 \text {, the most distal portion } \\
\text { of prolapse }>1 \mathrm{~cm} \text { below the plane of the hymen but } \\
\text { protrudes no further than } 2 \mathrm{~cm} \text { less than the total vaginal } \\
\text { length; and stage } 4 \text {, eversion of total lower genital tract } \\
\text { being essentially complete }\end{array}$ & $\begin{array}{l}\mathrm{n}=3730 \\
\text { Stage I: } 862 \\
\text { Stage II: } 683 \\
\text { Stage III: } 433 \\
\text { Stage IV: } 0 \\
\text { Stage } \geq \text { II: } 1116\end{array}$ & $\begin{array}{l}23.1 \% \\
18.3 \% \\
11.6 \% \\
0 \% \\
29.9 \%\end{array}$ \\
\hline $\begin{array}{l}\text { UAE }(2015)^{28} \\
\text { Age of women }:>30 \\
\text { yrs. }\end{array}$ & $\begin{array}{l}\text { The women were asked if they had a dragging lump } \\
\text { coming down in the vagina, lump coming out of vagina } \\
\text { or lump felt or seen outside the vagina. The presence of } \\
\text { any of these symptoms was considered to indicate the } \\
\text { presence of POP }\end{array}$ & $\begin{array}{l}n=429 \\
\text { POP: } 127\end{array}$ & $29.6 \%$ \\
\hline
\end{tabular}

\section{Risk factors related to pelvic organprolapse}

Out of the twelve studies that identified the prolapse status based on a gynecological examination, nine studies discussed the factors that were associated

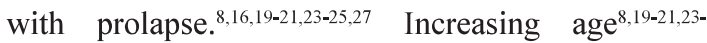
25,27, number of parity ${ }^{8,16,19-21,24,25,27}$, body mass index ${ }^{19,20,24,27}$ and fetal macrosomia ${ }^{20,23,27}$ were found to be the significant risk factors for prolapse in majority of the studies, irrespective to the country's economy. In context to the studies that assessed the associations of menopause with prolapse status, all three studies sampled in lower and lower-middle-income country suggested that menopause status increase the risk of prolapse $^{8,16,20}$ while in case of upper-middle-income country two studies found no significant relationship between prolapse and menopause $\mathrm{e}^{23,27}$ and only one study suggested the odds of prolapse increase (odds ratio (OR) 5.13 ; 95\% CI 1.90-7.43) with menopause..$^{25}$

Three studies conducted in the upper-middle-income countries suggested that cesarean section could be a protective factor for prolapse in comparison to vaginal delivery ${ }^{23,24,27}$ while one study suggested that having more than three vaginal deliveries, history of a vaginal delivery without episiotomy and history of operative delivery increases the odds of contacting prolapse. ${ }^{25}$ However, in the context of low and lowerupper income countries, no study analyzed the odds of prolapse among vaginal delivery or cesarean section. However, one study found that about hospital delivery, delivering at home or health center increased the odds of prolapse (odds ratio (OR) 1.2; 95\% CI $0.83-1.75) .{ }^{21}$ One study from Nepal suggested that there is statistical significant association between prolapse and factors such as age of firstdelivery $(<20$ years), delivery in squatting or standing position $(\mathrm{P}<0.05)^{16}$ and one study suggested that odds of prolapse increase if there is a history of problems with pregnancy (unadjusted odds ratio (UOR) 1.54; 95\% CI 1.18-1.99), mild (adjusted odds ratio (AOR) $1.29,95 \%$ CI $0.94-1.78$ ) or moderate/severe (AOR 2.12; 95\% CI 1.33-3.4) anemia and lower reproductive tract infection (UOR $1.34,95 \%$ CI $1.03-$ 1.75). ${ }^{19}$ The summary of hypothesized risk factors and significant risk factors analyzed in the selected studies areillustrated [Table- 4 and 5]. 
Table-4: Risk factors associated with clinically diagnosed POPin low and lower-middle-income countries.

\begin{tabular}{|c|c|c|}
\hline Study & Hypothesized risk factors & The result from significant risk factor \\
\hline $\begin{array}{l}\text { Tanzania; } \\
\text { Masenga et al } \\
(2018)^{21} \\
\text { Statistical } \\
\text { test: Logistic } \\
\text { regression }\end{array}$ & $\begin{array}{l}\text { Age: } 18-34,35-44,45-54,55-90 \\
\text { Occupation: Farmer, Business, } \\
\text { Others } \\
\text { Heavy work per day: } 0-1 \text { hrs, } 2-4 \text { hrs, } \\
5+\text { hrs } \\
\text { BMI: }<24,24-29,30+ \\
\text { Parity: } 0-2,3-4,5 \\
\text { Age first delivery: } 10-19,20-29,30- \\
40 \\
\text { Place of } 1^{\text {st }} \text { delivery: home or health } \\
\text { center, Hospital } \\
\text { Duration of } 1^{\text {st }} \text { labour: }<24 \text { hours, } \\
\geq 24 \text { hours }\end{array}$ & 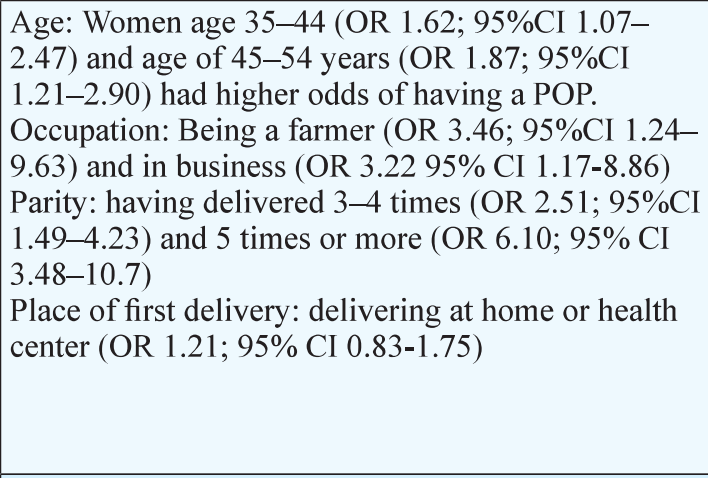 \\
\hline $\begin{array}{l}\text { Nepal; Lien et } \\
\text { al }(2012)^{16} \\
\text { Statistical test: } \\
\text { Chi-square } \\
\text { test }\end{array}$ & $\begin{array}{l}\text { Age: } 15-25,26-35,36-45.46-55,>55 \\
\text { Parity }>2 \\
\text { Age at } 1 \text { st delivery: }<20 \text { years } \\
\text { Menopause } \\
\text { Squatting /standing position during } \\
\text { delivery } \\
\text { The interval from delivery to work: } \\
4 \text { week }\end{array}$ & $\begin{array}{l}\text { Parity }>2(\mathrm{P}<0.05) \\
\text { Age at } 1 \text { st delivery: }<20 \text { years }(\mathrm{P}<0.05) \\
\text { Menopause: }(\mathrm{P}<0.05) \\
\text { Squatting or standing position during delivery: } \\
(\mathrm{P}<0.05) \\
\text { The interval from delivery to work: } \leq 4 \text { weeks } \\
(\mathrm{P}<0.05)\end{array}$ \\
\hline $\begin{array}{l}\text { Lebanon; } \\
\text { Awwad et } \\
\text { al }(2012)^{20} \\
\text { Statistical } \\
\text { test: Logistic } \\
\text { regression }\end{array}$ & $\begin{array}{l}\text { Age: } 40.42 \pm 9.34,31.78 \pm 9.56 \\
\text { years } \\
\text { Vaginal Parity: } 6.38 \pm 2.77 \text { vs } 3.53 \\
\pm 2.57 \\
\text { Increased BMI: }>24 \mathrm{~kg} / \mathrm{m}^{2}, \leq 24 \mathrm{~kg} / \\
\mathrm{m}^{2} \\
\text { Fetal macrosomia: } \geq 4,000 \mathrm{~g},<4,000 \\
\text { g } \\
\text { Miscarriage: One or more, None } \\
\text { Cesarean delivery: Yes, No } \\
\text { Operative vaginal delivery: Yes, No } \\
\text { Anemia: Hemoglobin }<12 \text {, } \\
\text { Hemoglobin } \geq 12 \\
\text { Smoking status: Ever smoker, Never } \\
\text { smoker } \\
\text { Previous gynecological surgical } \\
\text { operation; Menopause status; } \\
\text { Metabolic disorders; Hypertension; } \\
\text { Oral contraceptive use: Yes, No }\end{array}$ & $\begin{array}{l}\text { Age: } 40.42 \pm 9.34(\mathrm{RR}=1.0940 \mathrm{P}<0.0001) \\
\mathrm{BMI}:>24 \mathrm{~kg} / \mathrm{z}^{2}(\mathrm{UOR} 2.997 ; 95 \% \text { CI } 1.990-4.54 \text {, } \\
\mathrm{RR}=1.6242 \mathrm{P}=0.0483) \\
\text { Fetal macrosomia: } \geq 4,000 \mathrm{~g}(2.430 ; 95 \% \text { CI } 1.146- \\
5.153) \\
\text { Miscarriage: } \leq 1 \text { (UOR } 2.490 ; 95 \% \text { CI } 1.738-3.569 \text {, } \\
\mathrm{RR}=1.0832 \mathrm{P}=0.2943) \\
\text { Menopause status: Present (UOR } 3.297 ; 95 \% \mathrm{CI} \\
\text { 1.888-5.755) } \\
\text { Previous gynecological surgical operation: Present } \\
\text { (UOR 1.797; 95\% CI } 1.243-2.599) \\
\text { Metabolic disorders: Present (UOR 2.735; 95\% CI } \\
\text { 1.239-6.035) } \\
\text { Hypertension: Present (UOR 2.735; 95\% CI 1.239- } \\
\text { 6.035) } \\
\text { Anemia: Hemoglobin }<12 \text { (UOR 1.105; 95\% CI } \\
0.587-2.081) \\
\text { Smoking status: Ever smoker (UOR 1.360; 95\% CI } \\
0.954-1.939)\end{array}$ \\
\hline
\end{tabular}




\begin{tabular}{|c|c|c|}
\hline $\begin{array}{l}\text { Gambia; } \\
\text { Scherf et al } \\
(2002)^{19} \\
\text { Statistical } \\
\text { test: Logistic } \\
\text { regression }\end{array}$ & $\begin{array}{l}\text { Age (years): 15-24, 25-34, 35-44, } \\
45-54 \\
\text { Marital status: Monogamous, } \\
\text { Polygamous, Widowed/divorced, } \\
\text { Single } \\
\text { Grouped parity: Nulliparous, Para } \\
\text { 1-3, Para 4-7, Para 8+ } \\
\text { Currently pregnant: No, Yes } \\
\text { History of problems with pregnancy: } \\
\text { No, Yes } \\
\text { Deficient perineum: No, Yes } \\
\text { BMI: Normal, Underweight }(<18), \\
\text { Overweight/obese }(\text { BMI }>25) \\
\text { Anaemia: Not anemic, Mild }((\mathrm{Hb}< \\
11 \text { (pregnant), Hb }<12 \text { (non- } \\
\text { pregnant)), Moderate/severe }((\mathrm{Hb}< \\
9 \text { (pregnant), Hb }<10 \text { (non-pregnant)) } \\
\text { Lower reproductive tract infection: } \\
\text { No, Yes }\end{array}$ & $\begin{array}{l}\text { Age: } 25-34 \text { (AOR 1.29; 95\% CI 0.83-2.01), 35-44 } \\
\text { (AOR 1.6; 95\% CI 0.98-2.59), 45-54 (AOR 1.87; } \\
\text { 95\% CI 1.09-3.2) } \\
\text { Marital status: Polygamous (UOR 1.72; 95\% CI } \\
\text { 1.33-2.22), Widowed/divorced (UOR 1.1; 95\% } \\
0.52-2.29) \text {, Single (UOR 0.17; 95\% CI 0.02-1.42) } \\
\text { Grouped parity: Para 1-3(AOR 6.39; 95\% CI 2.24- } \\
\text { 18.22), Para 4-7 (AOR 11.69; 95\% CI 4.0-34.13), } \\
\text { Para 8+ (AOR 14.95; 95\% CI 4.94-45.24) } \\
\text { Currently pregnant: Yes (AOR 1.62; 95\% CI 1.11- } \\
\text { 2.38) } \\
\text { History of problems with pregnancy: Yes (UOR } \\
1.54 ; 95 \% \text { CI 1.18-1.99) } \\
\text { Deficient perineum: Yes (AOR 2.01; CI 1.52-2.64) } \\
\text { BMI: Underweight (UOR 0.91; 95\% CI 0.63-1.31), } \\
\text { Overweight/obese (UOR 1.33; 95\% CI 0.86-2.04) } \\
\text { Anaemia: Mild (AOR 1.29, 95\% CI 0.94-1.78), } \\
\text { Moderate/severe (AOR 2.12; 95\% CI 1.33-3.4) } \\
\text { Lower reproductive tract infection: Yes (UOR 1.34, } \\
\text { 95\% CI 1.03-1.75) }\end{array}$ \\
\hline $\begin{array}{l}\text { Ghana; Wusu- } \\
\text { Ansah }(2008)^{8} \\
\text { Statistical } \\
\text { test: Logistic } \\
\text { regression }\end{array}$ & $\begin{array}{l}\text { Age: } 15-24,25-34,35-44,45-54 \\
\geq 55 \\
\text { Menopause: No Yes } \\
\text { Parity: Nulliparous } 0,1-3,4-6, \geq 7\end{array}$ & $\begin{array}{l}\text { Age: } 25-34 \text { (OR 5.6; 95\% CI 0.7-26.5), 35-44 } \\
\text { (OR 3.4; 95\% CI 0.3-182.1), 45-54 (OR 16.9; 95\% } \\
\text { CI 1.7-86.6), } \geq 55 \text { (OR 27.8; 95\% CI 1.1-1469.1) } \\
\mathrm{P}<0.01 \\
\text { Menopause: Yes (OR 27.8; 95\% CI 1.1-1469.1) } \\
\mathrm{P}=0.02 \\
\text { Parity: } 1-3 \text { (Ref), 4-6 (OR 2.3; 95\% CI 0.7-7.2), } \geq 7 \\
\text { (OR 4.0; 95\% CI 1.1-14.8) P }<0.01\end{array}$ \\
\hline
\end{tabular}

Table-5: Risk factors associated with clinically diagnosed POP in upper-middle-income countries.

\begin{tabular}{|c|c|c|}
\hline Study & Hypothesized risk factors & The result from significant risk factor \\
\hline $\begin{array}{l}\text { China; Li } \\
\text { et al(2019) } \\
24 \\
\text { Statistical } \\
\text { test: } \\
\text { Logistic } \\
\text { regression }\end{array}$ & $\begin{array}{l}\text { Age: } 20-29,30-39,40-49,50-59 \text {, } \\
60-69, \geq 70 \\
\text { BMI: Normal (18.5-23.9), } \\
\text { Underweight }(<18.5), \text { Overweight } \\
(24-27.9), \text { Obese }(\geq 28) \\
\text { Parity: Primiparous }(=1), \\
\text { Nulliparous, Multiparous (=2), } \\
\text { Multiparous }(\geq 3) \\
\text { Delivery pattern: Vaginal } \\
\text { spontaneous delivery, Vaginal } \\
\text { assisted delivery, Cesarean section } \\
\text { Job: Physical labor, Mental labor } \\
\text { Alcohol consumption: No, Yes } \\
\text { Smoking: No, Yes } \\
\text { Cough ( }>3 \text { weeks): No, Yes } \\
\text { Constipation ( }>1 \text { year): No, Yes } \\
\text { Gynecological disease: No, Yes } \\
\text { Pelvic surgery: No, Yes }\end{array}$ & 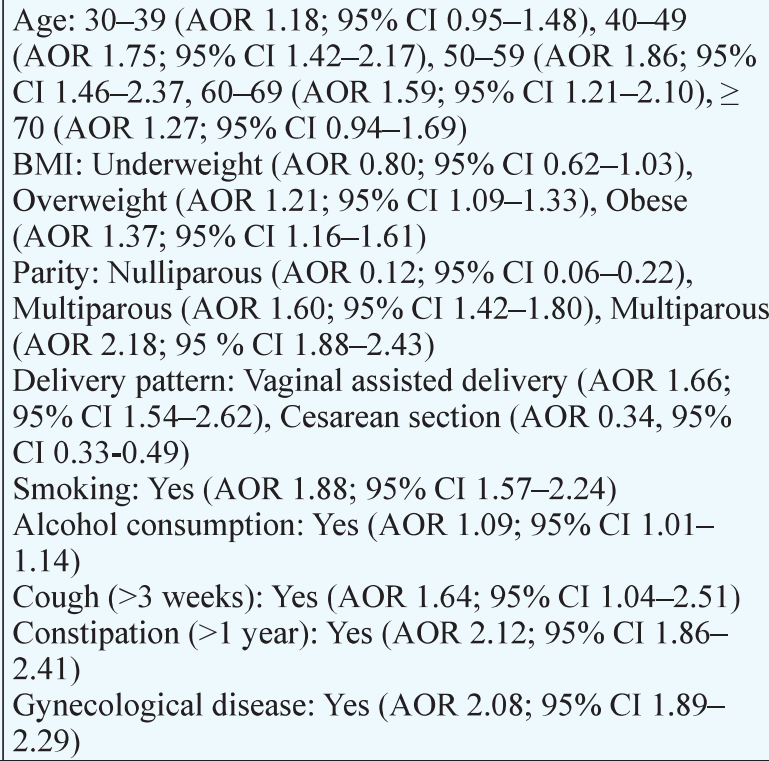 \\
\hline
\end{tabular}




\begin{tabular}{|c|c|c|}
\hline $\begin{array}{l}\text { Brazil; } \\
\text { Horst et al } \\
(2017)^{23} \\
\text { Statistical } \\
\text { test: } \\
\text { Logistic } \\
\text { regression }\end{array}$ & $\begin{array}{l}\text { Age (years): 18-25, 26-35, }>35 \\
\text { BMI: } 18.5-24.9,25.0-29.9, \geq 30 \\
\text { History of vaginal delivery: No, Yes } \\
\text { Birthweight }(\mathrm{g}): \leq 4,000,>4,000 \\
\text { Hysterectomy: No, Yes } \\
\text { Menopausal status: No, Yes } \\
\text { Hormone replacement therapy: No, } \\
\text { Yes } \\
\text { Diabetes: No, Yes; Asthma: No, Yes } \\
\text { Hypertension: No, Yes } \\
\text { Constipation: No, Yes; Smoking: } \\
\text { No, Yes }\end{array}$ & $\begin{array}{l}\text { Age (years): } 26-35 \text { (AOR 1.9; 95\% CI } 0.8-4.4),>35 \\
\text { (AOR 5.8; 95\% CI 2.6-13.0) P }<0.01 \\
\text { History of vaginal delivery: Yes (AOR 6.7, 95\% CI } \\
\text { 4.0-11.4) P <0.01 } \\
\text { Birthweight }(\mathrm{g}):>4,000 \text { (AOR 2.0; 95\% CI 1.0-4.2) } \\
\mathrm{P}=0.04 \\
\text { Hysterectomy: Yes (AOR 2.8; 95\% CI 0.9-8.4) } \mathrm{P}=0.06 \\
\text { Diabetes: Yes (AOR 2.7; 95\% CI 1.0-7.4) } \mathrm{P}=0.04\end{array}$ \\
\hline $\begin{array}{l}\text { Turkey; } \\
\text { Aytan et al } \\
(2014)^{27} \\
\text { Statistical } \\
\text { test: } \\
\text { t-test, Chi } \\
\text { squire test }\end{array}$ & $\begin{array}{l}\text { Age, years (mean } \pm \mathrm{SD}) \\
\text { Body mass index, } \mathrm{kg} / \mathrm{m} 2(\text { mean } \pm \\
\text { SD) } \\
\text { Waist-hip-ratio (mean } \pm \mathrm{SD}) \\
\text { Parity (mean } \pm \text { SD) } \\
\text { Cesarean delivery rate } \\
\text { Maximum birth weight, g (mean } \pm \\
\text { SD) } \\
\text { Postmenopausal }[\mathrm{n},(\%)] \\
\text { Chronic diseases }[\mathrm{n},(\%)] \\
\text { Smoking }[\mathrm{n},(\%)]\end{array}$ & $\begin{array}{l}\text { Age: No Prolapse }(39.0+11.1) \text { vs Prolapse }(42.8+9.4) \\
\mathrm{P}<0.001 \\
\text { BMI: No Prolapse }(26.3+4.6) \text { vs Prolapse }(27.8+4.8) \\
\mathrm{P}<0.001 \\
\text { Waist-hip-ratio: No Prolapse }(0.78+0.06) \text { vs Prolapse } \\
(0.80+0.07) \mathrm{P}<0.001 \\
\text { Parity: No Prolapse }(1.8+1.5) \text { vs Prolapse }(3.2+1.8) \\
\mathrm{P}<0.001 \\
\text { Cesarean delivery rate: No Prolapse }(200(20.8 \%)) \text { vs } \\
\text { Prolapse }(38(10.6 \%)) \mathrm{P}<0.001 \\
\text { Maximum birth weight, } \mathrm{g}: \text { No Prolapse }(3490+389) \text { vs } \\
\text { Prolapse }(3584+574) \mathrm{P}<0.001\end{array}$ \\
\hline $\begin{array}{l}\text { Iran; } \\
\text { Garshabi } \\
\text { et } \\
\text { al( }(2006)^{25} \\
\text { Statistical } \\
\text { test: } \\
\text { Logistic } \\
\text { regression }\end{array}$ & $\begin{array}{l}\text { Age: } \geq 50 \text { (year) } \\
\text { Parity: }>3 \\
\text { Gravidity: }>3 \\
\text { Number of abortions: } \geq 2 \\
\text { Number of vaginal delivery: }>3 \\
\text { History of home delivery } \\
\text { History of a vaginal delivery } \\
\text { without episiotomy } \\
\text { History of operative delivery } \\
\text { History of giving birth to the } \\
\text { macrocosmic infant } \\
\text { Menopausal status }\end{array}$ & $\begin{array}{l}\text { Age: } \geq 50 \text { (yr) (OR 4.46; 95\% CI } 2.06-18.63) \mathrm{P}<0.0001 \\
\text { Parity: }>3 \text { (OR 3.02; 95\% CI 2.06 }-18.63) \mathrm{P}<0.0004 \\
\text { Gravidity: }>3 \text { (OR 2.45; 95\% CI } 1.63-6.71) \mathrm{P}<0.0003 \\
\text { Number of vaginal delivery: }>3 \text { (OR } 5.90 ; 95 \% \text { CI } 2.46- \\
10.87) \mathrm{P}<0.0005 \\
\text { History of a vaginal delivery without episiotomy (OR } \\
2.91 ; 95 \% \text { CI } 1.9-6.94) \mathrm{P}<0.002 \\
\text { History of operative delivery (OR } 2.41 ; 95 \% \text { CI } 1.5- \\
3.75) \mathrm{P}<0.005 \\
\text { Menopausal status (OR 5.13; 95\% CI } 1.90-7.43) \\
\mathrm{P}<0.0001\end{array}$ \\
\hline
\end{tabular}

More to the findings of the selected studies, one study conducted in Nepal using ethnographic study and clinical study mixed design illustrated that among those women who knew about their prolapse status, one in four women reported trying traditional remedies. These remedies included ingesting special herbs or foods, hanging upside down, or inserting alcohol and herb-soaked cloth into the vagina regularly as well as visiting traditional healers (sudenis). They conducted special ceremonies and prescribed herbs and special foods along with instructing women on how to insert pessaries of alcohol and herbs. ${ }^{7}$ Similar to these findings, study sampled in one of the uppermiddle-income countries, Iran demonstrated that only 25 out of 151 women with stress incontinence sought standard interventions, whereas the other affected women used traditional methods or ignored the symptom considering it to be a usual symptom that every woman bears who had given birth. ${ }^{26}$

\section{DISCUSSION}

The current review has included 15 studies published between January 2000 and January 2020 reporting on the prevalence and risk factors of pelvic organ prolapse in countries of a different economy. The average prevalence of pelvic organ prolapse (stage I-IV) lies at $40.01 \%$ while the clinically significant prolapse ( $\geq$ Stage II) average at $33.27 \%$. $^{7,8,16,17,19-21,23-}$ ${ }^{27}$ Similarly, the studies that assessed prolapse status based on expressed symptoms found the prevalence of symptomatic prevalence to be at $19.5 \% \cdot{ }^{18,22,28} \mathrm{~A}$ similar phenomenon was observed in another systematic review by Barber et $\mathrm{al}^{29}$ which noted that the prevalence of pelvic organ prolapse defined by the symptoms ranged at 3-6\% which in case of the vaginal examination was up to $50 \%$. This suggests that there is a chance of under-reporting of prolapse prevalence when it is only measured based on symptomatic measures. Furthermore, in this review, we noted that 
the higher burden ofclinically significant prolapse ( $\geq$ Stage II) is directed towards the countries of the low and lower-middle economy with an average of $58.8 \%$ which in case ofthe higher economy lies at $20.35 \%$. $^{16,20,21,23-27}$ The prevalence of prolapse in the low and lower-middle-income countries in this study was also higher in comparison to a systematic review performed on thirty studies from developing nations, which reported mean prevalence of the POP at $19.7 \%$ with the prevalence range of $3.4 \%$ to $56.4 \%{ }^{5}$.

In this review, it has been noted that articles adopting probability sampling reported a slightly higher prevalence $(37.41 \%)$ of prolapse compared to studies using less rigorous sampling $(34.60 \%),{ }^{7,8,16-28}$ perhaps because those suffering from prolapse are less likely to volunteer in studies using a convenience sample. This suggests that many studies may underestimate the prevalence of prolapse as women with prolapse might not be visiting the health institutions during the time of the study. Different measures were used to diagnose and categorize POP status in the 15 publications included in this review. Eight studies used procedure of Valsalva maneuver performed in the dorsal lithotomy position to diagnose prolapse which was followed by Prolapse Quantification System (POP-Q) for the staging of POP illustrating the weighted prevalence of $33.27 \%$ (range: 9.23 $64.6 \%$ ) for prolapse of stage II-IV.16,20,21,23-27 Two studies performed speculum examination and bimanual examination of pelvis without staging prolapse through POP-Q thus yields a mean prevalence of $35.1 \%$ (range: $12.1 \%$ - $46 \%$ ) for prolapse of stage I-IV. ${ }^{8,19}$ Two studies didn't provide detailed information on the gynecological examination.,17 Two studies reported the use of the WHO subgroup tool to assess symptomatic prolapse ${ }^{18,22}$ and one studydiagnosed prolapse status based on symptoms expressed by the participants, ${ }^{28}$ providing the mean prevalence of symptomatic prolapse at $19.5 \%$ (range: $13.3 \%-29.6 \%$ ).

The risk factor for prolapse such as increasing age, number of parity, body mass index, and fetal macrosomia remains the major associated factors for prolapse in all nations, irrespective to their economy. ${ }^{8,16,19-21,24,25,27}$ However, some factors are more prevalent at in low and lower-middle income countries such as the age of first delivery, home delivery, delivery in squatting or standing position, anemia, history of pregnancy complication, an occupation that are more prevalent in countries with lower economy. ${ }^{16,19-21}$ These additional risk factors are mostly the consequences of poor service delivery system and standard of living as compared to countries of the higher economy. Increased age and parity were also found to be related to the prevalence of POP in a systematic review performed in thirty studies sampled in developing countries..$^{5}$ Additionally, some studies also suggested that there is statistically significant relationship that exists between prolapse status and certain behavior characteristics and chronic conditions such as smoking, ${ }^{20,24}$ alcohol consumption, ${ }^{24}$ hypertension, ${ }^{20}$ chronic cough, ${ }^{22}$ diabetes, ${ }^{23}$ metabolic disorders, ${ }^{20}$ and constipation. ${ }^{24}$ However, some studies also suggested that no statistically significant relationship exists between these attributes such as smoking, hypertension, constipation or any chronic diseases. ${ }^{23,27}$

Despite the intensive review, this review encountered several limitations. We confined our search only on the free accessed literature and limited paid assessed articles searched through the PubMed database and the study covers studies published in the last two decades. So, this paper may not cover all the published literature reporting prevalence and risk factors of pelvic organ prolapse. Out of the assessed literature, this paper primarily concentrated on the original articles either conducted in the community or health care facilities, while some of the studies followed convenience sampling making the findings less generalizable. For further assessment of the scientific literature on pelvic organ prolapse in different nations of varying economies, we suggest more systematic reviews on interventional studies and meta-analyses.

\section{CONCLUSIONS}

The low and lower-income countries have almost twice the burden of pelvic organ prolapse than the countries of the higher economy. The major risk factors associated with prolapse remains common in all countries irrespective of national income or development. However, the low- and lower-income countries have higher prevalence as they face additional risk factors which are mostly associated with service delivery and other health conditions. In this scenario, more priorities should be given for the prevention and management of prolapse and research in countries with low and lower-upper income economies. 


\section{DISCLOSURE}

The authors report no conflict of interest in this work. No violence of human rights and safety.

\section{FUNDING}

Nil.

\section{REFERENCES}

1. Haylen BT, de Ridder D, Freeman RM, Swift SE, Berghmans $\mathrm{B}$, Lee J, et al. An International Urogynecological Association (IUGA)/International Continence Society (ICS) joint report on the terminology for female pelvic floor dysfunction. Int Urogynecol J. 2010;21(1):5-26.[PubMed]

2. Ramaseshan AS, Felton J, Roque D, Rao G, Shipper AG, Sanses TVD. Pelvic floor disorders in women with gynecologic malignancies: a systematic review. Int Urogynecol J. 2018;29(4):459-76.[PubMed]

3. Gunasekera P, Sazaki J, Walker G. Pelvic organ prolapse: don't forget developing countries. Lancet. 2007;369(9575):178990. [PubMed][Link]

4. Vos T, Flaxman AD, Naghavi M, Lozano R, Michaud C, Ezzati M, et al. Years lived with disability (YLDs) for 1160 sequelae of 289 diseases and injuries 1990-2010: a systematic analysis for the Global Burden of Disease Study 2010. Lancet. 2012;380(9859):2163-96. [PMC free article]

5. Walker GJ, Gunasekera P. Pelvic organ prolapse and incontinence in developing countries: review of prevalence and risk factors. Int Urogynecol J. 2011;22(2):127-35. [PubMed]

6. The World Bank, World Bank Country and Lending Groups 2020. [Link]

7. Bonetti TR, Erpelding A, Pathak LR. Listening to "felt needs": investigating genital prolapse in western Nepal Reproductive Health Matters. 2004;12(23):166-75. [PubMed]

8. Wusu-Ansah OK, Opare-Addo HS. Pelvic organ prolapse in rural Ghana. Int J Gynaecol Obstet. 2008;103(2):121-4 [PubMed]

9. Doaee M, Moradi-Lakeh M, Nourmohammadi A, RazaviRatki SK, Nojomi M. Management of pelvic organ prolapse and quality of life: a systematic review and meta-analysis. Int Urogynecol J. 2014;25(2):153-63.[PubMed]

10. Komesu YM, Rogers RG, Rode MA, Craig EC, Gallegos KA, Montoya AR, et al. Pelvic floor symptom changes in pessary users. Am J Obstet Gynecol. 2007;197(6):620.e1-6.[PubMed]

11. Abdool Z, Thakar R, Sultan AH, Oliver RS. Prospective evaluation of the outcome of vaginal pessaries versus surgery in women with symptomatic pelvic organ prolapse. In Urogynecol J. 2011;22(3):273-8.[PubMed]

12. Lone F, Thakar R, Sultan AH. One-year prospective comparison of vaginal pessaries and surgery for pelvic organ prolapse using the validated ICIQ-VS and ICIQ-UI (SF) questionnaires. Int Urogynecol J. 2015;26(9):1305-12 [PubMed]

13. de Albuquerque Coelho SC, de Castro EB, Juliato CR. Female pelvic organ prolapse using pessaries: a systematic review. Int Urogynecol J. 2016;27(12):1797-803.[PubMed]

14. Hutton B, Salanti G, Caldwell DM, Chaimani A, Schmid $\mathrm{CH}$, Cameron $\mathrm{C}$, et al. The PRISMA extension statement for reporting of systematic reviews incorporating network meta-analyses of health care interventions: checklist and explanations. Ann Intern Med. 2015;162(11):777-84 [PubMed]

15. Loney PL, Chambers LW, Bennett KJ, Roberts JG, Stratford PW. Critical appraisal of the health research literature: prevalence or incidence of a health problem. Chronic Diseases in Canada. 1998;19(4):170-6.[PubMed]

16. Lien YS, Chen GD, Ng SC. Prevalence of and risk factors for pelvic organ prolapse and lower urinary tract symptoms among women in rural Nepal. Int J Gynaecol Obstet. 2012;119(2):185-8.[PubMed]

17. Gurung G, Amatya A, Bista K, Joshi A, Sayami J. Pelvic organ prolapse in rural Nepalese women of reproductive age groups: What makes it so common? Nepal J Obstet Gynecol. 2007; 2(2),35-41. [Link]

18. Henok A. Prevalence and Factors Associated with Pelvic Organ Prolapse among Pedestrian Back-Loading Women in Bench Maji Zone. Ethiop J Health Sci. 2017;27(3):263-72. [PubMed][PMC free article]

19. Scherf C, Morison L, Fiander A, Ekpo G, Walraven G Epidemiology of pelvic organ prolapse in rural Gambia, West Africa. BJOG. 2002;109(4):431-6.[PubMed]

20. Awwad J, Sayegh R, Yeretzian J, Deeb ME. Prevalence, risk factors, and predictors of pelvic organ prolapse: a communitybased study. Menopause. 2012;19(11):1235-41. [PubMed]

21. Masenga GG, Shayo BC, Rasch V. Prevalence and risk factors for pelvic organ prolapse in Kilimanjaro, Tanzania: A population-based study in Tanzanian rural community. PLOS ONE. 2018;13(4):e0195910. [PubMed][PMC free article]

22. Akter F, Gartoulla P, Oldroyd J, Islam RM. Prevalence of, and risk factors for, symptomatic pelvic organ prolapse in rural Bangladesh: a cross-sectional survey study. Int Urogynecol J. 2016;27(11):1753-9.[PubMed]

23. Horst W, do Valle JB, Silva JC, Gascho CLL. Pelvic organ prolapse: prevalence and risk factors in a Brazilian population Int Urogynecol J. 2017;28(8):1165-70. [PubMed]

24. Li Z, Xu T, Li Z, Gong J, Liu Q, Zhu L. An epidemiologic study of pelvic organ prolapse in rural Chinese women a population-based sample in China. Int Urogynecol J 2019;30(11):1925-32. [Europe PMC]

25. Garshasbi A, Faghih-Zadeh S, Falah N. The status of pelvic supporting organs in a population of Iranian women 18 - 68 years of age and possible related factors. Arch Iran Med 2006;9(2):124-8. [PubMed]

26. Tehrani FR, Simbar M, Abedini M. Reproductive morbidity among Iranian women; issues often inappropriately addressed in health-seeking behaviors. BMC Public Health 2011;11(1):863. [Link]

27. Aytan H, Ertunc D, Tok EC, Yasa O, Nazik H. Prevalence of pelvic organ prolapse and related factors in a general female population. Turkish J Obstet Gynecol. 2014;11(3):176-80 [PMC free article]

28. Elbiss HM, Osman N, Hammad FT. Prevalence, risk factors and severity of symptoms of pelvic organ prolapse among Emirati women. BMC Urology. 2015;15:66.[PMC free article]

29. Barber MD, Maher C. Epidemiology and outcome assessment of pelvic organ prolapse. Int Urogynecol J. 2013;24(11):178390. [PubMed] 